\title{
The Quality of HOTS-Based Science Questions Developed by Indonesian Elementary School Teachers
}

\author{
Naufal Ishartono ${ }^{*}$, Anatri Desstya ${ }^{2}$, Harun Joko Prayitno ${ }^{3}$, Yasir Sidiq ${ }^{4}$ \\ 1,2,3,4 Universitas Muhammadivah Surakarta, Indonesia
}

\section{A R T I C L E I N F O}

Article history:

Received April 06, 2021

Revised April 08, 2021

Accepted May 04, 2021

Available online May 25, 2021

Kata Kunci:

Higher Order Thinking Skills,

Soal IPA, Case Study

Keywords:

Higher Order Thinking Skills,

Science Question, Case Study

\begin{abstract}
A B S T RA K
Di Indonesia, beberapa pelatihan telah dilakukan untuk mengembangkan soal IPA berbasis HOTS untuk guru tingkat sekolah dasar. Namun, masih sedikit hasil penelitian yang mengkaji tentang bagaimana kualitas soal IPA berbasis HOTS yang dikembangkan oleh guru sekolah dasar. Oleh karena itu, penelitian ini bertujuan untuk menganalisis kualitas soal IPA berbasis HOTS yang dikembangkan oleh guru sekolah dasar di Indonesia. Penelitian ini merupakan penelitian studi kasus dengan pendekatan deskriptif-analitik. Subjek penelitian ini adalah 60 soal IPA berbasis HOTS yang dikembangkan oleh guru-guru tingkat sekolah dasar di Kabupaten Boyolali, Indonesia, pada tanggal 22 Februari 2020. Penelitian ini melibatkan dua orang penilai dari salah satu perguruan tinggi di Indonesia dimana keduanya berlatar belakang ahli pendidikan tingkat sekolah dasar. Aspek yang dinilai adalah aspek kesesuaian dengan kriteria soal HOTS, kesesuaian dengan kriteria kemampuan berpikir siswa SD, dan kesesuaian dengan kualitas soal yang baik. Hasil penelitian ini menunjukkan bahwa banyak soal muatan IPA berbasis HOTS yang tidak memenuhi aspek pertama, terutama pada poin non-algorithmic, multiple ways, dan multiple interpretation. Selanjutnya, pada aspek kedua, sebagian besar soal tidak menggunakan ilustrasi untuk memperkuat informasi soal yang dikembangkan. Aspek ketiga adalah aspek yang relatif terpenuhi oleh soal-soal yang telah dikembangkan. Harapannya, hasil dari penelitian ini dapat menjadi bahan evaluasi bagi para pengambil kebijakan di bidang pendidikan untuk meningkatkan kualitas pelatihan pengembangan soal IPA berbasis HOTS untuk jenjang sekolah dasar di Indonesia.
\end{abstract}

\section{A B S T R A C T}

In Indonesia, several training pieces have been conducted to develop HOTS-based science questions for elementary school teachers. However, few studies examine how elementary school teachers developed HOTS-based science questions. Hence, the current study is a case study that aims to analyze HOTS-based science questions developed by elementary school teachers in Indonesia. This study employed a descriptive-analytical method by analyzing 60 HOTS-based science questions developed by elementary school teachers in Boyolali, Indonesia, on February 22, 2020. This study involved two raters from one of Indonesia's universities, who are experts in assessing learning for elementary school level to assess the questions. The aspects that are assessed are aspects of conformity with HOTS questions criteria, conformity with the criteria of thinking ability of elementary school students, and conformity with the quality of good questions. This study's findings show that many problems do not meet the first aspect, especially at non-algorithmic points, multiple ways, and multiple interpretations. Next, in the second aspect, most of the question does not use illustration to strengthen the developed question's information. The third aspect is a relatively fulfilled aspect by most developed questions. However, only a few developed questions are judged not to meet this aspect. Hopefully, this study's findings can be an evaluation material for policymakers in education to increase the training quality of HOTS-based science questions for elementary school level in Indonesia.

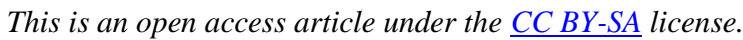

Copyright @ 2021 by Author. Published by Universitas Pendidikan Ganesha.

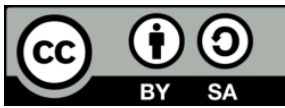

\section{INTRODUCTION}

In 2018, PISA released ranking results of countries related to the quality of student literacy levels in each member country. In general, the index of student literacy levels in Indonesia towards science increased by three points from 2006 to 2018. However, Indonesia's ranking stands at 70 on science literacy which lags far behind some other Southeast Asian countries such as Malaysia, Brunei Darussalam, and Singapore (OECD, 2018). Indonesia's low ranking in PISA illustrates how the level of higher-order thinking skills (HOTS) of Indonesian students is still relatively low (Fathiara, Badarudin, \& Muslim, 2019; Putranta \& Supahar, 2019). HOTS is a skill in understanding the faced reality, concluding the facts, linking the facts with the possessed knowledge, and solving it (Ichsan et al., 2019; Pratama \& Retnawati, 2018). In other words, these skills will arise when someone consciously uses their prior knowledge to solve their problem (Abosalem, 2016; Saraswati 
\& Agustika, 2020). The learning process that uses HOTS as the basis in the process can increase the learning process's meaning because students memorize the materials taught, understand, analyze, and implement their knowledge to solve problems (Hassan, Rosli, \& Zakaria, 2016). HOTS is a higher way of thinking than memorizing facts, presenting facts, or applying rules, formulas, and procedures (Andoko, 2020; Nurmala \& Mucti, 2019). HOTS skills are when he is already in the top three levels in the revised Bloom's Taxonomy, namely at the analysis, evaluation, and creation stage (Fadzam \& Rokhimawan, 2020). Some previous studies have shown that mastery of HOTS can improve critical thinking skills, creative thinking, logical and reflective thinking (Indah, 2020; King, Goodson, \& Rohani, 2010; Yamin, Saputra, \& Deswila, 2020; Zulfiani, Suwarna, \& Sumantri, 2020).

HOTS-based learning has been widely integrated into many subjects in Indonesia, including science subjects at the elementary school level (Ani Rahmawati, Nur Lailatin Nisfah, 2019; Silwana, Subanji, Manyunu, \& Rashahan, 2020). Some previous studies show that the application of HOTS-based science learning positively impacts elementary school students, such as improving students' activity and the ability to analyze, evaluate, and create (Lestari, 2019; Rozi \& Hanum, 2019). However, the fact that the level of student science literacy in Indonesia is still relatively low shows that there needs to be HOTS-based science learning habituation from an early age, namely at the elementary school level. One form of habituation is by giving science questions to students as often as possible. Continuous exercises will familiarize students to have HOTS skills in subject science. Therefore, the aspect that should be given more attention on the teacher aspect, namely how teachers develop HOTS-based science questions for the elementary school level.

Several training pieces have been conducted in Indonesia to develop HOTS-based science questions for elementary school teachers (Danial \& Sanusi, 2020; Sari, Cahyaningtyas, Maharani, Yustiana, \& Kusumadewi, 2019; Supriyadi, Rusilowati, Isnaeni, \& Winarsih, 2019). In addition, there have also been many previous studies that examined the application of HOTS-based learning on science subjects at the elementary school level (Kumala, Setiawan, \& Shaleha, 2020; Suratmi, Laihat, Asnimar, \& Ela Okta Handini, 2020; Yasin et al., 2019). However, few studies examine how the quality of HOTS-based science questions developed by elementary school teachers. This is important to be further reviewed since many teachers have not adequately explained the concept of HOTS, and this is likely to affect the quality of HOTS-based science questions developed by them (Parmin, Sajidan, Ashadi, \& Sutikno, 2015; Yusoff \& Seman, 2018, Dinatha \& Kua, 2019). Principally, there are three types of questions: descriptive, relational, and causal. In the context of science, those three types of questions can be used as HOTS-based science questions. The questions must be matched with the characteristics of HOTS problems in the subject of science for the elementary school level. Some aspects that should be considered in developing HOTS-based science questions for the elementary school level are the HOTS problem's criteria, the characteristics of elementary school students, and the quality aspect of good questions.

In terms of the characteristics of HOTS questions, some researchers have their own opinions. HOTS problems' characteristics are non-algorithmic, complex, multiple solutions, involving variations in decisionmaking and interpretation, application of multiple criteria, and effortfulness (Pratiwi, 2017; Umami, Rusdi, \& Kamid, 2021). The HOTS problem's characteristics should lead to critical thinking and creative thinking skills (Conklin, 2012; Saraswati \& Agustika, 2020). The characteristics of HOTS problems are to have the nature of (1) transfer of one concept to another, (2) process and apply information, (3) seek links from different information, (4) use information to solve problems, and (5) study ideas and information critically. From these three opinions, the author tends to modify the criteria of good HOTS questions to (1) complex questions that involve many concepts, (2) non-algorithmic questions meaning that action steps cannot be entirely determined at the beginning, (3) need more than one way, (4) involving variations in decision-making and interpretation to work on them, and (5) use much information to solve the problem (Andoko, 2020; Nurmala \& Mucti, 2019).

In terms of elementary school students' characteristics, the context of student characteristics studied in this study is students' characteristics in thinking. Elementary school students' thinking characteristics are still at the formal stage, which means that it is still on concrete materials that are easy to see and feel by the senses and simple to be understood (Anwariningsih \& Ernawati, 2013; Cherry, 2020). So, the points that must be seen are that the HOTS problem must (1) have a clear illustration for students to see and (2) use simple language. Another aspect that is needed to be considered is the aspect of the question quality. To compose a good question, consider the following points: (1) material points that should be according to the indicator. In this context, the material should be valid because it satisfies the science subject curriculum for the elementary school level. (2) Construction points covering the question shall be formulated expressly, clearly, unambiguously, and using good Indonesian language rules. From the aforementioned explanations, the aspects that need to be fulfilled to develop HOTS-based science questions can be seen in Table 1. 
Table 1. The Aspects of Good HOTS-Based Science Questions

\begin{tabular}{cl}
\hline Aspects & \multicolumn{1}{c}{ Point } \\
\hline \multirow{3}{*}{ Characteristics of HOTS questions } & Complex: involve many concepts \\
& Non-algorithmic questions \\
& Multiple ways to solve \\
& Involve variations in decision making and interpretation \\
& Needs multiple information to solve \\
Characteristics of elementary school & Using illustration to depict the problem \\
students & Using words that is simple to be understood \\
& The material should be valid \\
& Unambiguously \\
& Grammatically clear of Indonesian language \\
\hline
\end{tabular}

Based on the background above, this study's research problem is how good the quality of HOTS-based science questions developed by elementary school teachers in Indonesia. Therefore, this study aims to analyze the quality of HOTS-based science questions developed by elementary school teachers in Indonesia. The results of this study are expected to provide benefits in the form of consideration materials for stakeholders in the field of teacher training in Indonesia in conducting HOTS-based science learning training for elementary school level teachers.

\section{METHOD}

The present study is a case study that used a descriptive-analytical method that identifies and reflects trends and variations in populations, creating new measures of crucial phenomena, identifying causal effects, and descriptive analyses are part of almost every empirical paper and report. (Loeb et al., 2017; Bancong \& Song, 2018). The subjects of this study were 60 elementary school teachers from Boyolali city, Indonesia, who had minimum teaching experience for five years and were selected using purposive sampling techniques. The selection technique was based on the background of the teachers who had previously received training in developing HOTS-based science questions. At the same time, this study's object is the quality of HOTS-based science questions developed by the teachers.

The data type in this study is qualitative data that is HOTS-based science questions developed by the research subjects and interview transcripts, and quantitative data that is the result of the scores of HOTS-based science questions that have been developed. To collect the data, three techniques were done, such as using documentation and interviews to collect the qualitative data and observation to collect quantitative data. The documentation technique was used to documenting the questions developed by the teachers. The observation technique in this context was done by scoring the quality of the developed questions using the quality points described in Tabel. One and using 4-scale Likert's score that was categorized from 1 to 4 which consecutively described as "Very Disagree", "Disagree", "Agree", and "Strongly Agree". The scoring instrument has been first conducted validation test (using Aiken's value test and reliability tests where obtaining valid and reliable results. Two experts who qualified as an expert in science education evaluation from a private university in Indonesia were engaged in the scoring. The two experts' assessment results were then analyzed by using Cohen's Kappa inter-rater reliability test (using software SPSS 16.0) to determine the agreement's percentage rate (McHugh, 2012). If both experts' agreement level is strong (minimum score is $80 \%$ ), then the assessment results can be used and further analyzed. At the same time, the interview was done to strengthen the data obtained by the authors. The collected data was then analyzed quantitatively by calculating and classifying the developed questions into two groups: questions that were scored 3 to 4 (feasible questions) and scored 1 to 2 (unfeasible questions). The results of the classification are then presented in the form of diagrams for further qualitative description.

\section{RESULT AND DISCUSSION}

This research lasted for one day on February 26, 2020, engaging 60 elementary school teachers who had previously received training related to the development of HOTS-based questions. The 60 teachers came from 37 different elementary schools in Boyolali city and were gathered in an elementary school for the research purpose. The teachers were invited to attend and asked to develop a HOTS-based science question to obtain 60 HOTSbased science questions. Next, the 60 questions are assessed and analyzed by experts both quantitatively and qualitatively. This study's results are divided into three aspects: the conformity aspect of the problem developed with the characteristics of the HOTS problem, the aspect of conformity with the thinking characteristics of 
elementary school students, and the aspect of conformity with good quality standards of questions. Before the authors analyzed the experts' results, the value obtained from Cohen's Kappa inter-rater reliability test for both experts' assessment results is $81.5 \%$, which means the experts' agreement rate is relatively strong and can be continued subsequent analysis (see Table 2).

Tabel 2. Cohen's Kappa Inter-Rater Reliability Test Result

\begin{tabular}{lcccc}
\hline & Value & $\begin{array}{c}\text { Asymp. Std. } \\
\text { Error }^{\mathbf{a}}\end{array}$ & Approx. T $^{\mathbf{b}}$ & Approx. Sig. $^{\text {Appos }}$ \\
\hline Measure of Agreement Kappa & 0.815 & 0.079 & 6.316 & 0.000 \\
N of Valid Cases & 60 & & & \\
\hline
\end{tabular}

a. Not assuming the null hypothesis

b. Using the asymptotic standard error assuming the null hypothesis

In general, based on the assessment of experts related to the 60 HOTS-based science questions, it was obtained that none of the questions got a perfectly average score (that is 4) from the three aspects evaluated. It was also found that the highest average value per question of all developed questions is 3.67. At the same time, the lowest average value is 2.167 . If the average score for all problems developed, then the average score is 2.68 , which means that the quality of HOTS-based science questions developed is still relatively low (See Table. 3).

Table 3. The Average Scores Recapitulation of The Two Raters

\begin{tabular}{lccccc}
\hline & N & Minimum & Maximum & Mean & Std. Deviation \\
\hline Raters' Average Score & 60 & 2.17 & 3.67 & 2.8689 & 0.41415 \\
Valid N (listwise) & 60 & & & & \\
\hline
\end{tabular}

This aspect consists of five points, namely the complexity of the problem, non-algorithmic, has many ways to solve it, involves variations in decision making and interpretation, and requires much information to solve it. The recap of the HOTS-based science questions assessment that has been developed is reviewed from the first aspect can be seen in Figure 1. The data shown is only a percentage of the number of questions that scored three or four for each rating point to simplify data presentation.

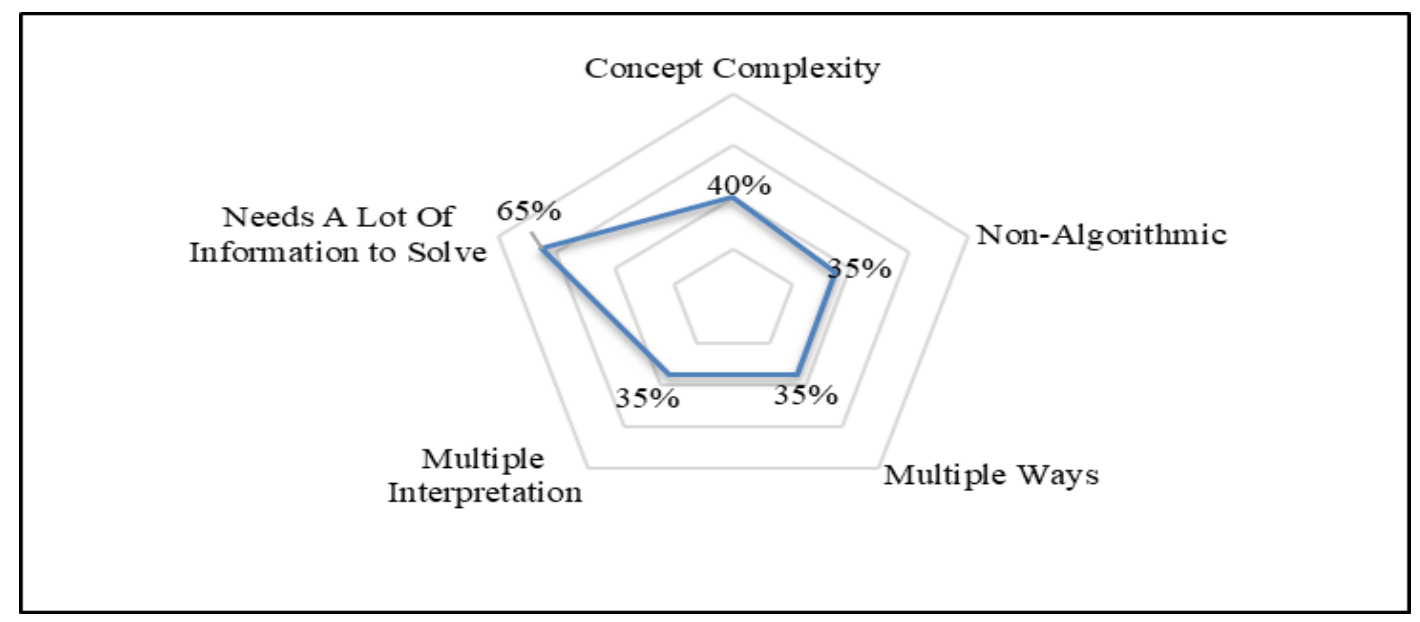

Figure 1. Recapitulation of rater's assessment results on conformity aspect with the characteristics of HOTS questions

In general, Figure 1. depicts that the fifth point, which is the point about "Needs much information to solve," is the most fulfilled point of the developed questions, which is as much as $65 \%$, followed by the point "Concept Complexity" of $40 \%$. Interestingly, the other three points follow with a $35 \%$ percentage point fullness rate. This aspect consists of two points, namely points (1) using illustration to depict the problem and (2) using words/sentence that is easy to be understood. The recapitulation of the assessment results of experts for the second aspect can be seen in Figure 2. The majority of developed questions fail to meet the first point: the use of illustration to clarify the question, where only $40 \%$ of the developed questions meet this point. In contrast, as many as $85 \%$ or more of the three-fourth number of questions developed meets the second point, which is related to ease in students understanding the words/or sentences used in HOTS-based science questions developed. This 
third aspect is the related aspect of the suitability of the questions developed with the quality standards of the questions that Table 1 has two points, namely the validity points of the developed questions, as well as the clarity points of the developed questions where in this context the question does not have a double meaning (ambiguous). The recapitulation of this third aspect can be seen in Figure 3.

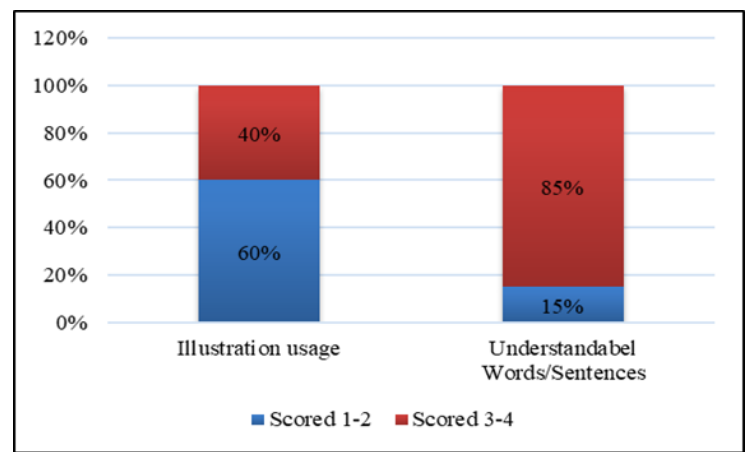

Figure 2. Recapitulation of experts' assessments Result in conformity with the thinking characteristics of elementary school students

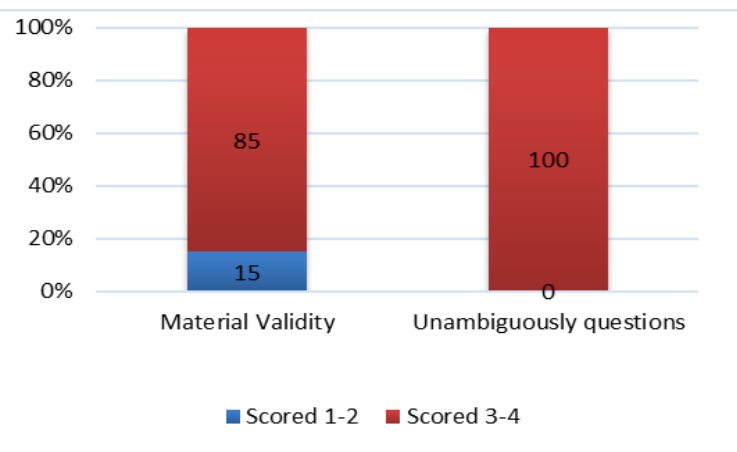

Figure 3. Recapitulation of experts' assessments result on conformity with the characteristics of a good question

From Figure 4, when viewed from the material validity aspect of the developed question, it can be seen that as many as $85 \%$ are classified as valid, and the remaining $15 \%$ are invalid from the material side. While from the point of unambiguous questions, interestingly, it appears that all the problems developed do not have an ambiguous sentence or has two meanings.

In developing HOTS-based questions, it must undoubtedly be appropriate and meet the points of good HOTS questions. Figure 2 depicts that the most dominant point fulfilled from the 60 HOTS-based science questions that have been developed is at the point "Needs much information to solve," which is $65 \%$. This means that as much as $35 \%$ of the developed problems have not involved variations in the information used to solve them. One example of the 35\% problems that do not meet this point is in Figure 4.

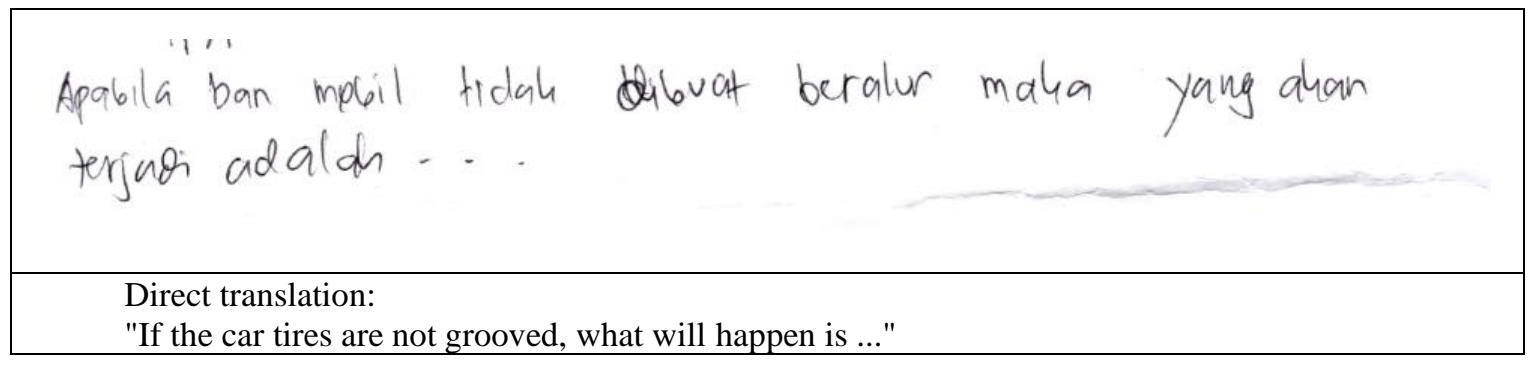

Figure 4. The sample of the developed question that does not meet the point of "Needs much information to solve"

The problem in Figure 4 is about the elementary school level for physics. Based on the experts' interview, the question shown in Figure 4 was judged by experts not to meet the point "Needs much information to solve" because the question does not use prologue or introductory information. In HOTS-based questions, prologues are very important to accommodate what information students need to analyze to solve the problem (Ichsan et al., 2019; Umami et al., 2021). Not only on that point, the question is also judged not to meet the other four points. The first is on the point of the complexity of the problem. The concept used to work on the problem is the friction force concept only, which can be developed by integrating it into the braking force. Implementing one concept into two concepts will increase the complexity of the problem (Nurmala \& Mucti, 2019; Sagala \& Andriani, 2019). Next, the point of non-algorithmic where the question has only one direct answer, that is, the tire will be quickly slipping. The quality of a good HOTS problem must not be routine, which means that it cannot be easily answered by only using one way (Afrita \& Darussyamsu, 2020). To solve the questions, students must involve many concepts and much prior knowledge that they have (Harta, Rasuh, \& Seriang, 2020).

Next is the third point: to have multiple interpretations where the question is not complex. Based on this point, the question only has one interpretation asking what happens if the tire is not well-grooved. To fulfil this 
point, the question should be made and constructed to solve the problem; the students should think twice or more (Fadzam \& Rokhimawan, 2020; Pratama \& Retnawati, 2018). The last is the point of multiple ways to solve where in HOTS question, there are many ways to solve it (Tanudjaya \& Doorman, 2020). On the contrary, the question in Figure 4 is a routine question with only one way to answer. Therefore, the last point is not fulfilled because the way of completion is only one way. Because the purpose of the development of HOTS-based science questions is for elementary school students, it is mandatory to consider aspects of elementary school students' thinking characteristics in the process of development. There are two points assessed in this aspect: the point of use of illustration and understanding the language or word used. Regarding the first point, only $40 \%$ of the developed questions meet that point. Also, out of $40 \%$ of the questions, no one gets a perfect score of 4 . The majority of questions developed do not use illustration to strengthen the information about the developed. The definition of illustration in this context is an illustration in the form of images. This is by research which states that elementary school students tend to understand information visually (Raiyn, 2016; Ulia \& Sari, 2018). One example of a question that does not meet the first point is the question in Figure 5. Meanwhile, the question that is considered to give a good enough illustration even though it is not appropriate in theory can be seen in Figure 5 .

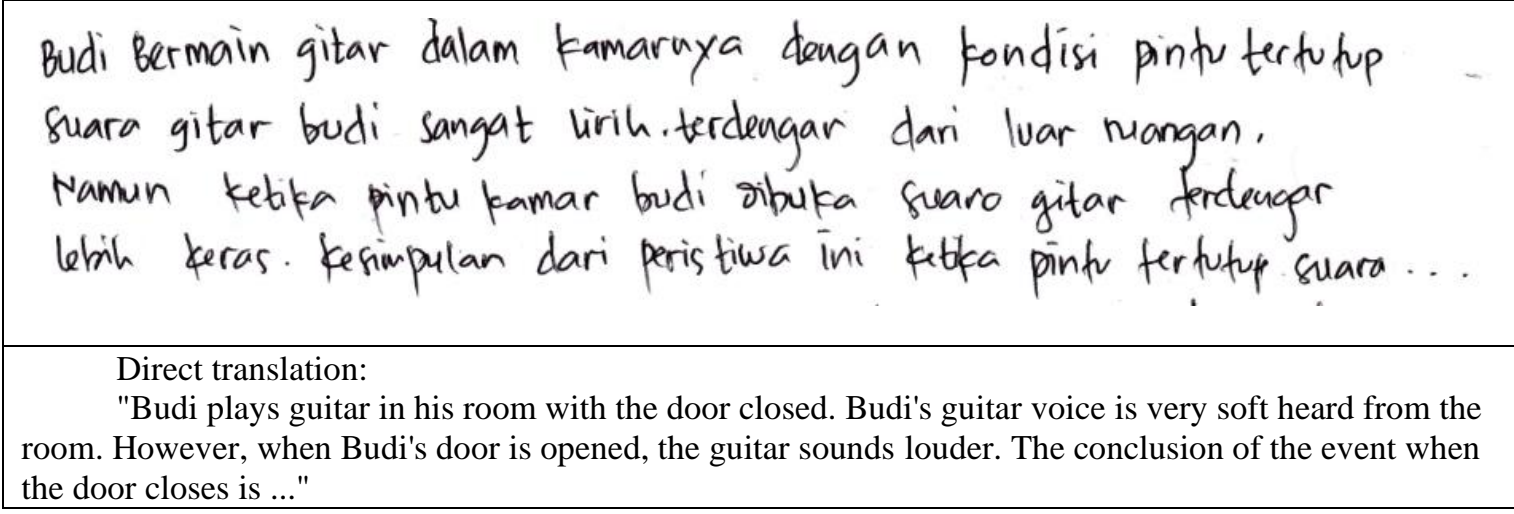

Figure 5. One example of a question that gives illustration even though it is not perfect

Experts judge the problem in Figure 5 to illustrate the condition that the developer wants to illustrate even if the question is not illustrated using images. The illustration of the question is in the form of a narrative related to Budi's room condition while playing guitar. This illustration is considered sufficient to help students imagine the meaning of the developed question. Next is the point related to understandable words/sentences, where this point becomes a measure of how easy elementary school-age students can understand the words or sentences in the question. The parameters are at the simplicity of the selection of words and sentences used in the question. From the results described in Figure 2., only $15 \%$ of the questions developed using words /sentences were judged not easy to understand by elementary school students which one example is on Figure 6.

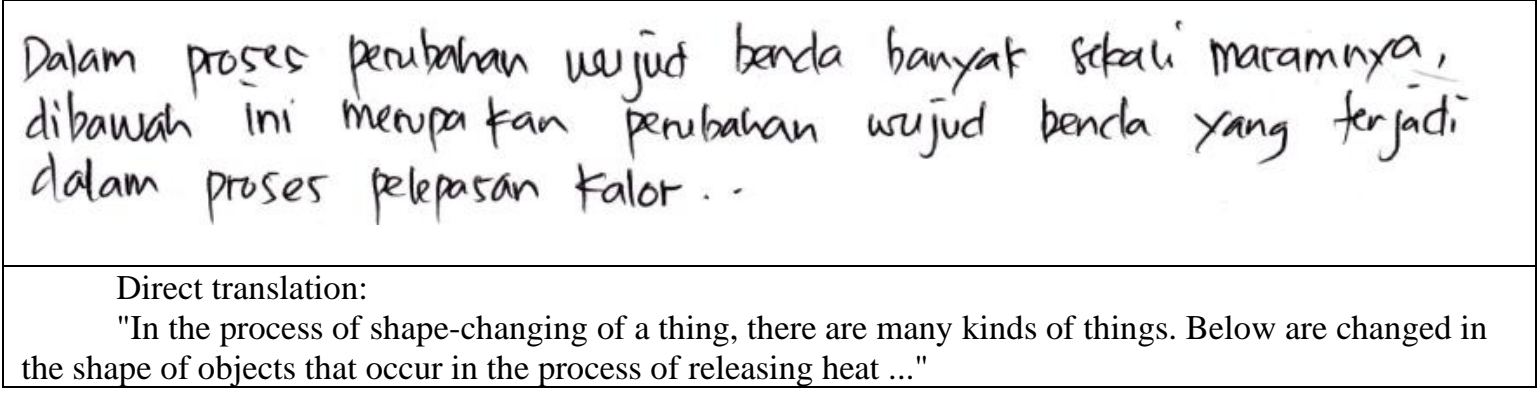

Figure 6. An example of a question with the selection of words/sentences that students do not easily understand

From the Indonesian aspect, the question in Figure 6. is not easy for students to understand. It is not because of the used words but rather the construction of inappropriate sentences such as commas. The inappropriateness of using a comma will make it has a double meaning which later will confuse the readers (Fauzi, Komalasari, \& Malik, 2017; Irwandi, 2020). It would be better if the sentence becomes "The process of changing the form of an object has many kinds. Therefore, here are the process of changing the form of an object 
that undergoes heat release". Besides, the instructions of the question are also unclear: whether students are required to choose the correct answer from the list of incorrect answer options, or vice versa. Writing questions that are not easy to understand will make it difficult for students to work on the question (Hulukati \& Rahmi, 2020; Sari et al., 2019). This aspect discusses whether the developed question is in accordance with the excellent method of writing the question. Two points must be fulfilled in this aspect: material validity and unambiguousness of the problem. In the current study, the material's validity is seen from whether the problem developed is in accordance with the critical theory and in accordance with the used curriculum, wherein this context is the standard of competence. While what is meant by the ambiguity of the question is whether the developed question has a double meaning that results in whether the student is confused or not to understand the information and intent of the developed question (Lukum, 2015; Lukum \& Astin., 2015). From Figure 3., it is obtained that the number of questions that meet the first point is as much as $85 \%$, or $15 \%$ of the developed questions are considered invalid. According to experts, invalidity is solely due to the incompatibility of the developed questions to Indonesia's primary school curriculum's standard of competence. One example of $15 \%$ of the question can be seen in Figure 7.

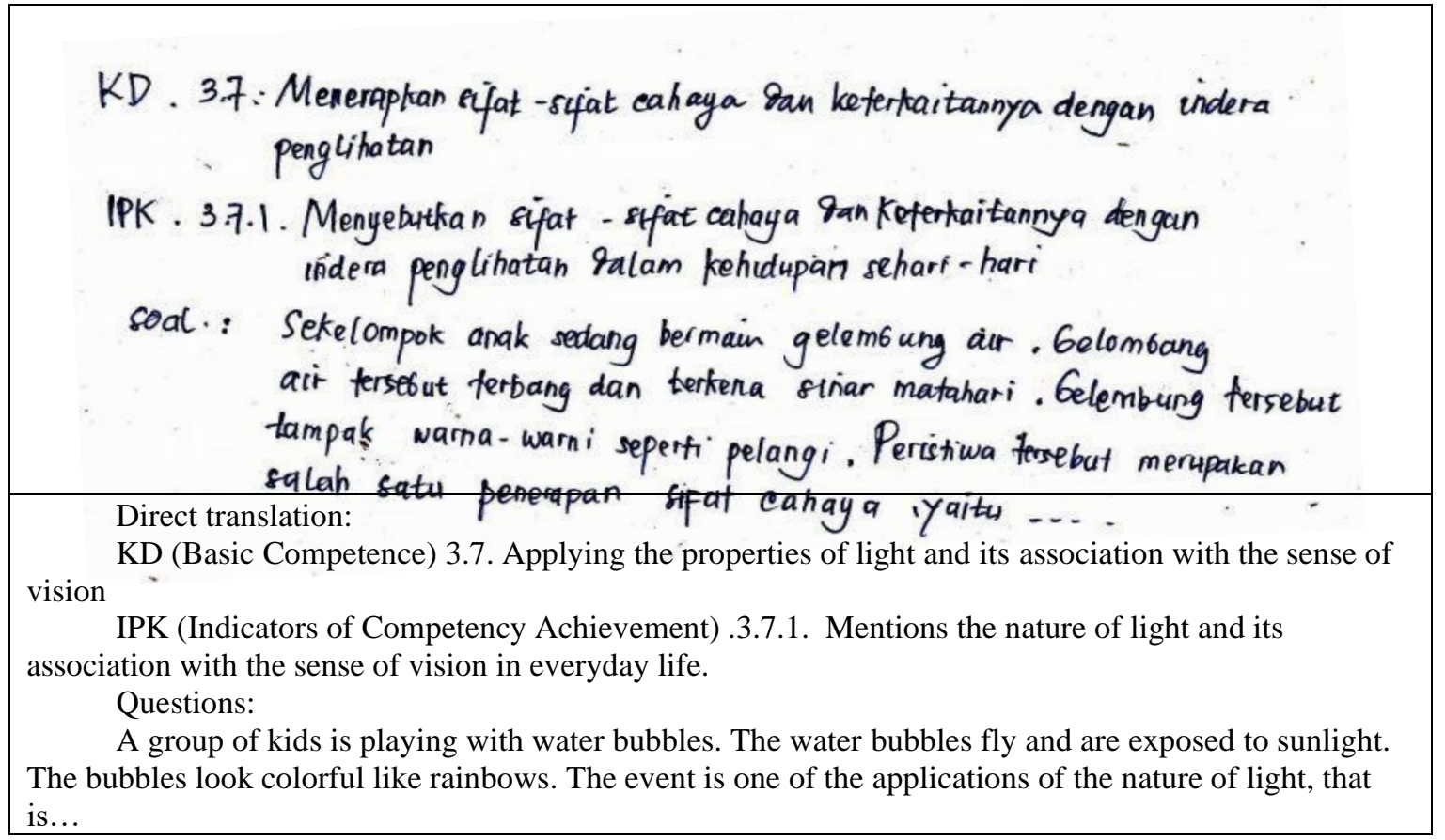

Figure 7. Examples of invalid questions

In terms of material validity, the question presented in Figure 7 is in accordance with the basic competency formulation but not in accordance with the formulation of competency achievement indicators. Material validity provides evidence on the extent of the targeted problem construction's suitability for specific assessment purposes (Enas Almanasreh, Moles, \& Timothy, 2019; Rahmawati, Budiyono, \& Wardi, 2017). In the Regulation of the Indonesian Minister of Education and Culture of Indonesia Number 24 of 2016, it is stated that essential competencies are the minimum learning skills and materials that students must achieve for a subject in each education unit that refers to the core competencies. The question in figure 8 shows conformity with students' ability to apply the properties of light and its association with the sense of vision. So, in this context, it is said that the material is invalid. The question shoots about the type of light properties presented through contextual illustrations.

In the perspective of IPK, the question is less valid because there is a discrepancy between the behavior to be measured (in this case, it is "mentioning the properties of light.....") and the editor of the question (in this case, it is analyzing the nature of the existing light based on the phenomenon presented). Another finding is that the behavior to be measured is still low order thinking skills (LOTS), while the question has been HOTS. Competency Achievement Indicator is the achievement of essential competencies characterized by measurable behavior. IPK is also a guide in compiling and developing the form, technique, and type of assessment to measure, assess, and evaluate the learning that has been done. With the findings of this material's validity, it is necessary to conduct mentoring activities for teachers in developing IPK and HOTS problems through sustainable professional development. Next is the point about ambiguity, where based on Figure 3., it is obtained 
that all developed questions are judged to have no problem with ambiguity. This means that the developed question has a clear purpose and is judged not to confuse the student with the question developed

\section{CONCLUSION}

Analysis related to the development of HOTS-based science questions by elementary school teachers should be a concern to grow and improve the atmosphere of high-level thinking from an early age. Based on the results of this study, it was obtained that the quality of problems developed by elementary school teachers in Indonesia, especially in the city of Boyolali, is still relatively low. From aspects of conformity with HOTS questions' characteristics, there are still many questions that do not meet the points in this aspect where only the point of "needs much information to solve" is met by most developed questions. As for the other four points, it is still great homework to fix. Next is on conformity with the characteristics of thinking elementary school students where most questions developed are judged not to meet the points of use illustration. This study's results can be a picture for policymakers in the world of education, especially in Indonesia, to give full attention to the quality of HOTS-based science questions developed by elementary school teachers.

\section{REFERENCES}

Abosalem, Y. (2016). Assessment techniques and students' higher-order thinking skills. International Journal of Secondary Education, 4(1), 1-11. https://doi.org/10.11648/j.ijsedu.20160401.11.

Afrita, M., \& Darussyamsu, R. (2020). Validitas Instrumen Tes Berpikir Tingkat Tinggi (HOTS) pada Materi Sistem Respirasi di Kelas XI SMA. Jurnal Mangifera Edu, 4(2). https://doi.org/10.31943/mangiferaedu.v4i2.83.

Andoko. (2020). Peningkatan Hots Dan Prestasi Belajar Melalui Metode Inkuiri Kelas 7C SMPN 1 Wonosobo Tahun Pelajaran 2018/2019. Spektra: Jurnal Kajian Pendidikan Sains, 6(1). https://doi.org/10.32699/spektra.v6i1.134.

Ani Rahmawati, Nur Lailatin Nisfah, S. K. (2019). The Capability Analysis of High Order Thinking Skills (HOTS) on Dynamic Electricity Material in Junior High School. JPPPF: Jurnal Penelitian Dan Pengembangan Pendidikan Fisika, 5(3). https://doi.org/10.21009/1.05211.

Anwariningsih, \& Ernawati. (2013). Development of Interactive Media for ICT Learning at Elementary School based on Student Self Learning. Journal of Education and Learning, 7(2), 121-128. http://dx.doi.org/10.11591/edulearn.v7i2.226.

Bancong, H., \& Song, J. (2018). Do physics textbooks present the ideas of thought experiments?: A case in Indonesia. Jurnal Pendidikan IPA Indonesia, 7(1), 25-33. https://doi.org/10.15294/jpii.v7i1.12257.

Cherry, K. (2020). The Formal Operational Stage of Cognitive Development.

Conklin, W. (2012). Higher-Order Thinking Skills to Develop 21 st Century Learners. Huntington Beach: Shell Educational Publishing, Inc.

Danial, M., \& Sanusi, W. (2020). Penguatan Kompetensi Guru Sekolah Dasar dalam Mengembangkan Instrumen Tes Kognitif Berbasis HOTS. PENGABDI: Jurnal Hasil Pengabdian Masyarakat, 1(2), 101110.

Dinatha, N. M., \& Kua, M. Y. (2019). Pengembangan Modul Praktikum Digital Berbasis Nature of Science (Nos) Untuk Meningkatkan Higher Order Thinking Skill (Hots). Journal of Education Technology, 3(4), 293. https://doi.org/10.23887/jet.v3i4.22500.

Enas Almanasreh, E., Moles, R., \& Timothy, M. (2019). Evaluation of methods used for estimating content validity. Research in Social and Administrative Pharmacy, 15(2), 214-221. https://doi.org/10.1016/j.sapharm.2018.03.066.

Fadzam, I. A., \& Rokhimawan, M. A. (2020). Analisis Materi Ipa Kelas Iv Tema Indahnya Kebersamaan Dengan HOTS. Jurnal Ilmiah Didaktika: Media Ilmiah Pendidikan Dan Pengajaran, 21(1). https://doi.org/10.22373/jid.v21i1.5970.

Fathiara, A., Badarudin, B., \& Muslim, A. H. (2019). Meningkatkan Keterampilan Berpikir Kritis Dan Gemar Membaca Peserta Didik Melalui Model Predict Observe Explain Berbasis Literasi. Muallimuna : Jurnal Madrasah Ibtidaiyah, 4(2), 92-101. https://doi.org/10.31602/muallimuna.v4i2.1863.

Fauzi, H. A., Komalasari, K., \& Malik, Y. (2017). Utilization of Audio Visual Media to Improve Student Learning Result in IPS Learning. International Journal Pedagogy of Social Studies, 2(1), 88-103. https://doi.org/10.17509/ijposs.v2i1.8666.

Harta, J., Rasuh, N. T., \& Seriang, A. (2020). Using HOTS-Based Chemistry National Exam Questions to Map the Analytical Abilities of Senior High School Students. Journal of Science Learning, 3(3), 143-148. https://doi.org/10.17509/jsl.v3i3.22387. 
Hassan, S. R., Rosli, R., \& Zakaria, E. (2016). The Use of i-Think Map and Questioning to Promote HigherOrder Thinking Skills in Mathematics. Creative Education, 07(07), 1069-1078. https://doi.org/10.4236/ce.2016.77111.

Hulukati, W., \& Rahmi, M. (2020). Instrumen Evaluasi Karakter Mahasiswa Program Pendidikan Guru Pendidikan Anak Usia Dini. Jurnal Obsesi: Jurnal Pendidikan Anak Usia Dini, 4(2). https://doi.org/10.31004/obsesi.v4i2.468.

Ichsan, I. Z., Sigit, D. V., Miarsyah, M., Ali, A., Arif, W. P., \& Prayitno, T. A. (2019). HOTS-AEP: Higher order thinking skills from elementary to master students in environmental learning. European Journal of Educational Research, 8(4), 935-942. https://doi.org/10.12973/eu-jer.8.4.935.

Indah, P. (2020). Development of HOTS (High Order Thinking Skill) Oriented Learning Through Discovery Learning Model to Increase The Critical Thinking Skill of High School Students. International Journal of Chemistry Education Research, 3(3). https://doi.org/10.20885/ijcer.vol4.iss1.art4

Irwandi. (2020). Penggunaan Media Audio Visual Dalam Peningkatan Hasil Belajar Materi Rukun Iman Pada Siswa Kelas I SD Negeri 49 Kota Banda Aceh. Pionir Jurnal Pendidikan, 9(1), 25-44. http://dx.doi.org/10.22373/pjp.v7i1.3321

King, F. J., Goodson, L., \& Rohani, F. (2010). Assessment \& evaluation educational services program: Higherorder thinking skills. Washington DC: A publication of the Educational Services Program.

Kumala, F. N., Setiawan, D. A., \& Shaleha, P. R. (2020). Contextual-Based Animal Encyclopedia: HOTS on Elementary School's Students. 2nd International Conference on Education and Social Science Research (ICESRE 2019) Contextual-Based, 417(Icesre 2019), 132-137. https://doi.org/10.2991/assehr.k.200318.025

Lestari, W. (2019). Keterikatan HOTS dengan Keaktivan Siswa dalam Pembelajaran IPA Sekolah Dasar. SEMINAR NASIONAL PENDIDIKAN DASAR. Purworejo: Universitas Muhammadiyah Purworejo.

Loeb, S., Dynarski, S., Mcfarland, D., Morris, P., Reardon, S., \& Reber, S. (2017). Descriptive analysis in education: A guide for researchers. Washington, DC: U.S.Department of Education, Institute of Education Science, National Center for Education and Evaluation, and Regional Assistance.

Lukum, A. (2015). Evaluasi Program Pembelajaran Ipa Smp Menggunakan Model Countenance Stake. Jurnal Penelitian Dan Evaluasi Pendidikan, 19(1), 25-37. https://doi.org/10.21831/pep.v19i1.4552.

Lukum, \& Astin. (2015). Evaluasi Program Pembelajarn IPA SMP Menggunakan Model Contenance Stake. Jurnal Penelitian Dan Evaluasi Pendidikan, 19(1), 25-37. https://doi.org/10.21831/pep.v19i1.4552.

McHugh, M. L. (2012). Interrater reliability: the kappa statistic. Biochemia Medica, 22(3), 276-282.

Nurmala, \& Mucti, A. (2019). Efektivitas Penggunaan Lkm Berbasis Hots (Higher Order Thinking Skills) Terhadap Hasil Belajar Mahasiswa Pendidikan Matematika. Journal of Hanoi Math, 2(2). https://doi.org/10.30862/jhm.v2i2.67.

OECD. (2018). Programme For International Student Assessment (PISA) Result From PISA 2018: Indonesia.

Parmin, Sajidan, Ashadi, \& Sutikno. (2015). Skill of prospective teacher in integrating the concept of science with local wisdom model. Jurnal Pendidikan IPA Indonesia, 4(2), 120-126. https://doi.org/10.15294/jpii.v4i2.4179.

Pratama, G. S., \& Retnawati, H. (2018). Urgency of Higher Order Thinking Skills (HOTS) Content Analysis in Mathematics Textbook. Journal of Physics: Conference Series, 1097(1). https://doi.org/10.1088/17426596/1097/1/012147.

Pratiwi, P. H. (2017). Pengembangan Modul Mata Kuliah Penilaian Pembelajaran Sosiologi Berorientasi HOTS. Cakrawala Pendidikan, 36(2). https://doi.org/10.21831/cp.v36i2.13123.

Putranta, H., \& Supahar. (2019). Synthesis of the Cognitive Aspects' Science Literacy and Higher Order Thinking Skills (HOTS) in Chapter Momentum and Impulse. Journal of Physics: Conference Series, 1397(1). https://doi.org/10.1088/1742-6596/1397/1/012014.

Rahmawati, Budiyono, \& Wardi. (2017). Pengembangan Modul Pembelajaran Digital Berbasis Visual Basic for Application (VBA) PowerPoint. Indonesian Journal of Curriculum and Educational Technology Studies, 5(1). https://doi.org/10.15294/ijcets.v5i1.14248.

Raiyn, J. (2016). The Role of Visual Learning in Improving Students' High-Order Thinking Skills. Journal of Education and Practice, 7(24), 115-121.

Rozi, F., \& Hanum, C. B. (2019). Pembelajaran IPA SD Berbasis HOTS (Higher Order Thinking Skills ) Menjawab Tuntutan Pembelajaran Di Abad 21. Seminar Nasional Pendidikan Dasar Universitas Negeri Medan, 1(4), 246-311.

Sagala, P. N., \& Andriani, A. (2019). Development of Higher-Order Thinking Skills (HOTS) Questions of Probability Theory Subject Based on Bloom's Taxonomy. Journal of Physics: Conference Series, 1188(1). https://doi.org/10.1088/1742-6596/1188/1/012025.

Saraswati, P. M. S., \& Agustika, G. N. S. (2020). Kemampuan Berpikir Tingkat Tinggi Dalam Menyelesaikan Soal HOTS Mata Pelajaran Matematika. Jurnal Ilmiah Sekolah Dasar Undiksha, 4(2). 
http://dx.doi.org/10.23887/jisd.v4i2.25336.

Sari, Y., Cahyaningtyas, A. P., Maharani, M. M., Yustiana, S., \& Kusumadewi, R. F. (2019). Meningkatkan kemampuan menyusun soal IPA berorientasi HOTS bagi guru Sekolah Dasar Gugus Pandanaran Dabin IV UPTD Semarang Tengah. Indonesian Journal of Community Services, 1(2), 175-183.

Silwana, A., Subanji, S., Manyunu, M., \& Rashahan, A. A. (2020). Students' Responses Leveling in Solving Mathematical Problem Based on SOLO Taxonomy Viewed from Multiple Intelligences. Indonesian Journal on Learning and Advanced Education (IJOLAE), 3(1), 1-16. https://doi.org/10.23917/ijolae.v3i1.10528.

Supriyadi, Rusilowati, A., Isnaeni, W., \& Winarsih, R. (2019). Peningkatan Kemampuan Guru SD di Kecamatan Gajah Mungkur dalam Menyusun Soal HOTS setelah Mengikuti Pelatihan. Seminar Nasional Paasarjana 2019, 382.

Suratmi, Laihat, Asnimar, \& Ela Okta Handini. (2020). Teachers understanding of HOTS based assessment in elementary schools. The 2nd International Conference on Elementary Education, 2(23), 1157-1164. Universitas Pendidikan Indonesia.

Tanudjaya, C. P., \& Doorman, M. (2020). Examining higher order thinking in Indonesian lower secondary mathematics classrooms. Journal on Mathematics Education, 11(2), 277-300. https://doi.org/10.22342/jme.11.2.11000.277-300.

Ulia, N., \& Sari, Y. (2018). Pembelajaran Visual, Auditory dan Kinestetik Terhadap Keaktifan dan Pemahaman Konsep Matematika Siswa Sekolah Dasar. Al Ibtida: Jurnal Pendidikan Guru MI, 5(2). https://doi.org/10.24235/al.ibtida.snj.v5i2.2890.

Umami, R., Rusdi, M., \& Kamid, K. (2021). Pengembangan Instrumen Tes Untuk Mengukur Higher Order Thinking Skills (Hots) Berorientasi Programme For International Student Asessment (Pisa) Pada Peserta Didik. JP3M: Jurnal Penelitian Pendidikan Dan Pengajaran Matematika, 7(1). https://doi.org/10.37058/jp3m.v7i1.2069.

Yamin, M., Saputra, A., \& Deswila, N. (2020). Enhancing Critical Thinking in Analyzing Short Story "The Lazy Jack" Viewed from Identity Theory. Indonesian Journal on Learning and Advanced Education (IJOLAE), 3(1), 30-39. https://doi.org/10.23917/ijolae.v3i1.9948.

Yasin, J. H. M., No, L., Gowa, K., Selatan, S., Ilmu, F., \& Iain, K. (2019). Higher Order Thinking Skills Assessment Based on Environmental Problem (HOTS-AEP): Mendesain Evaluasi Pembelajaran Abad 21 Ilmi. Jurnal Biotek, 7(1), 48-57.

Yusoff, W. M. W., \& Seman, S. C. (2018). Teachers' Knowledge of Higher Order Thinking and Questioning Skills: A Case Study at a Primary School in Terengganu, Malaysia. International Journal of Academic Research in Progressive Education and Development, 7(2), 45-63. https://doi.org/10.6007/ijarped/v7i2/4120.

Zulfiani, Suwarna, I. P., \& Sumantri, M. F. (2020). Science adaptive assessment tool: Kolb's learning style profile and student's higher order thinking skill level. Jurnal Pendidikan IPA Indonesia, 9(2), 194-207. https://doi.org/10.15294/jpii.v9i2.23840. 